\title{
Implementasi Kecerdasan Emosional dalam Kepemimpinan Sekolah di SMK Muhammadiyah Suruh Kabupaten Semarang
}

\author{
Ida Zahara Adibah \\ Fakultas Agama Islam Universitas Darul Ulum Islamic Centre Sudirman GUPPI Ungaran \\ idazaharaadibah@gmail.com
}

Naskah diterima: 13 April 2020 | Disetujui: 21 Juli 2020 | Diterbitkan: 12 Agustus 2020

\begin{abstract}
This study intends to examine the implementation of emotional intelligence-based school leadership in SMK Muhammadiyah Suruh in Semarang Regency, where the researcher obtained the research indicators from the Fleishman's dimension of leadership: initiating structure and consideration. From the initiative dimension are 1) leader's ethos, 2) initiative intuition, and 3) allocation of responsibility, while from the dimension of leader's consideration are 1) attention to works result and the process to gain it, as well as 2) attention to employee's welfare. This qualitative research is employed with case study design and proceed with the data collection through interviews, participatory observation, and documentation studies. The results of this study are 1) the leader has implemented the leadership initiatives, proved by effective and efficient works by organizing rights and obligations of the school's components, and 2) thanks to the excellent consideration, the leader could maintain a good condition of the school. The leader also continued to improve the employee's welfare by increasing their income and successfully increase knowledge and skills both of the teacher and employee.
\end{abstract}

Keywords: consideration, emotional intelligence, Fleishman, initiative, school leadership.

\begin{abstract}
Abstrak
Penelitian ini bertujuan untuk menguji implementasi kepemimpinan sekolah berbasis kecerdasan emosional di SMK Muhammadiyah Suruh Kabupaten Semarang, di mana peneliti menggunakan indikator penelitian dari dimensi kepemimpinan Fleishman: inisiatif dan perhatian. Dari dimensi inisiatif terdapat 1) etos pemimpin, 2) intuisi inisiatif, dan 3) alokasi tanggung jawab, sedangkan dari dimensi perhatian pemimpin adalah 1) perhatian pada hasil karya dan proses untuk mendapatkannya, serta 2) perhatian pada kesejahteraan karyawan. Penelitian kualitatif ini menggunakan desain studi kasus dan dilanjutkan dengan pengumpulan data melalui wawancara, observasi partisipatif, dan studi dokumentasi. Hasil penelitian ini adalah 1) pimpinan sekolah telah melaksanakan inisiatif kepemimpinan, dibuktikan dengan kerja efektif dan efisien dalam mengatur hak dan kewajiban warga sekolah, dan 2) berkat perhatian yang sangat baik, pimpinan dapat memelihara kondisi sekolah dengan baik. Pimpinan juga terus meningkatkan kesejahteraan karyawan dengan meningkatkan penghasilannya dan berhasil pula meningkatkan pengetahuan dan keterampilan baik bagi guru maupun karyawan.
\end{abstract}

Kata kunci: Fleishman, inisiatif, kecerdasan emosional, kepemimpinan sekolah, perhatian 


\section{Pendahuluan}

Dalam perspektif kebijakan pendidikan nasional (Depdiknas, 2006) terdapat tujuh peran utama kepala sekolah, yaitu sebagai: pendidik, pengelola, administrator, supervisor, pemimpin, pencipta iklim kerja, dan wirausahawan. Dengan demikian, kepala sekolah adalah pemimpin pendidikan yang bertanggung jawab menciptakan lingkungan belajar kondusif yang memungkinkan anggotanya untuk mendayagunakan dan mengembangkan potensinya seoptimal mungkin (Fauziyati, 2019).

Dalam lingkungan seperti itu, para guru dan peserta didik termotivasi untuk saling belajar, saling memotivasi, dan saling memberdayakan. Suasana seperti itu memberi ruang untuk saling belajar melalui keteladanan, belajar bertanggung jawab, serta belajar mengembangkan kompetensi sepenuhnya, bukan sekedar kompetensi kognitif (Poniman et al., 2017). Kepala sekolah seharusnya berada di garda paling depan dalam hal peneladanan, pemotivasian, dan pemberdayaan (Yusuf \& Mardiana, 2020). Hal ini senada dengan yang ungkapan populer dari tokoh pendidikan Ki Hadjar Dewantara, ing ngarsa sung tuladha, ing madya mangun karsa, tut wuri handayani.

Kepemimpinan pendidikan mengacu pada kualitas tertentu yang harus dimiliki kepala sekolah untuk dapat mengemban tanggung jawabnya agar berhasil. Pertama, kepala sekolah harus tahu persis apa yang ingin dicapainya (visi) dan bagaimana mencapainya (misi). Kedua, kepala sekolah harus memiliki sejumlah kompetensi untuk melaksanakan misi guna mewujudkan visi tersebut. Ketiga, kepala sekolah harus memiliki karakter tertentu yang menunjukkan integritasnya (Dharma dalam Darwin, 2014).

Dalam konsep kepemimpinan pendidikan sekolah, pendidikan digambarkan sebagai tempat berlangsungnya kepemimpinan sekaligus menentukan model kepemimpinan yang harus dilakukan dalam usaha mencapai cita-cita pendidikan. Seorang pemimpin yang sukses haruslah seorang yang memiliki pengaruh yang kuat dalam menjalankan fungsi dan perannya, seorang yang memiliki landasan iman dan takwa yang baik, serta karakteristik kepribadian tertentu yang terpuji, karena dirinya akan menjadi cerminan atau teladan bagi semua anggotanya (Baisa, 2005).

Kepemimpinan sebagai kemampuan dan kesiapan serta kesanggupan seorang untuk mempengaruhi, mendorong, mengarahkan serta mengajak orang-orang yang ada di sekitarnya untuk bekerja dan berusaha mewujudkan tujuan yang dicita-citakan sangat memerlukan kecerdasan (Wahyuni, 2019). Kecerdasan yang dimaksudkan adalah kemampuan untuk mengatur diri sendiri dan hubungannya dengan orang lain secara efektif. Kecerdasan dalam kepemimpinan sekolah sangat membantu seorang kepala sekolah dalam mempengaruhi stakeholder sehingga secara sukarela mengarahkan perilakunya pada pencapaian tujuan organisasi (Goleman, 2015a: 13-14).

SMK Muhammadiyah Suruh Kabupaten Semarang yang berdiri sejak 1998 dengan empat program keahlian yaitu Teknik Sepeda Motor, Teknik Garmen, Teknik Otomotif, dan Teknik Listrik memiliki jumlah peserta didik kurang lebih 800 siswa. Terletak di Desa Suruh Kecamatan Suruh Kabupaten Semarang, lebih kurang 30 km dari Kota Ungaran, SMK Muhammadiyah Suruh termasuk salah satu sekolah swasta yang berpengaruh nomor tiga di Kabupaten Semarang yang berjumlah kurang lebih 44 SMK baik negeri maupun swasta.

Atas dasar realitas tersebut dan dengan pertimbangan bahwa keberhasilan sebuah lembaga sekolah tentu tidak terlepas dari pengaruh pimpinannya, maka penulis tertarik untuk melakukan penelitian dan mengkaji lebih dalam tentang bagaimana karakteristik kepemimpinan sekolah di 
SMK Muhammadiyah Suruh ini. Dan secara khusus, karakteristik kepemimpinan tersebut penulis kaji dalam perspektif kecerdasan emosional.

\section{Metode Penelitian}

Penelitian ini menggunakan metode kualitatif, dengan menggunakan latar alami (natural setting) sebagai sumber data langsung mengenai kepemimpinan sekolah, baik yang berhubungan dengan cara pendekatan, teknik, maupun interaksi yang terjadi antara kepala sekolah dengan para guru. Data yang telah dikumpulkan dianalisis secara induktif dan hasilnya disajikan dalam bentuk deskriptif, yaitu dalam bentuk kata-kata.

Rancangan (desain) yang digunakan dalam penelitian ini adalah studi kasus. Data yang dikumpulkan melalui penelitian ini adalah data yang sesuai dengan rumusan masalah yaitu bagaimanakah karakteristik kepemimpinan di SMK Muhammadiyah Suruh dalam perspektif kecerdasan emosional.

Jenis data dalam penelitian ini dibedakan menjadi dua yaitu data primer dan data sekunder. Data primer diperoleh dalam bentuk kata-kata atau ucapan lisan dari perilaku subjek berkaitan dengan kepemimpinan SMK Muhammadiyah Suruh. Data sekunder bersumber dari dokumendokumen dan foto-foto yang dapat digunakan sebagai pelengkap data primer. Adapun teknik pengumpulan data yaitu dengan wawancara mendalam terhadap narasumber: Haryu Efendi (Kepala Sekolah), Bambang Sudiyono (Wakil Kepala Sekolah Bidang Kurikulum), dan Lilik Maskuroh (Bendahara), pengamatan peran serta, dan dokumentasi. Pengambilan data secara langsung dari lokasi penelitian di SMK Muhammadiyah Suruh, Kabupaten Semarang, dilaksanakan pada kurun waktu 13 hingga 15 Juli 2019. Kemudian, terhadap data yang telah terkumpul, dilakukan teknik analisis menggunakan analisa deskriptif yang meliputi reduksi data, penyajian data, dan penarikan kesimpulan.

\section{Memahami Kepemimpinan Sekolah}

Kepemimpinan sekolah terutama ditujukan kepada para guru karena merekalah yang terlibat secara langsung dalam proses pendidikan. Namun demikian, kepemimpinan kepala sekolah juga ditujukan kepada para tenaga kependidikan lainnya serta siswa. Hal ini senada dengan Wahjosumidjo (2001: 21) mengenai peran kepala sekolah sebagai pemimpin sekolah memiliki tanggung jawab menggerakkan seluruh sumber daya yang ada di sekolah sehingga melahirkan etos kerja dan produktifitas yang tinggi dalam mencapai tujuan.

Teori-teori kepemimpinan sesungguhnya merupakan pilihan bagi seorang pemimpin dalam berperilaku untuk mengoptimalkan kapasitas, kapabilitas, dan kepribadian. Adapun perilaku pemimpin menurut Nawawi (2006: 85) dibedakan menjadi delapan: otokrasi, otokrasi yang disempurnakan, birokrat, pelindung dan penyelamat, memajukan dan mengembangkan organisasi, pelaksana, kompromi, dan pembelot. Dalam konteks yang digunakan dalam penelitian ini, kepemimpinan ditekankan kepada dua aspek atau dimensi perilaku sebagaimana dikembangkan oleh Fleishman pada tahun 1955 (Goleman, 2015b: 56) yaitu dimensi struktur perbuatan inisiatif dan dimensi yang menyangkut hubungan antara atasan dan bawahan yang dinamakan dimensi perhatian. 


\section{Dimensi Kepemimpinan: Inisiatif}

Setiap manusia yang energik memiliki inisiatif terhadap sesuatu hal. Inisiatif merupakan suatu ide atau gagasan yang muncul ketika seseorang berhadapan dengan suatu peluang maka ia akan memunculkan ide untuk memanfaatkan peluang tersebut untuk direalisasikan. Kepemimpinan yang berdimensi inisiatif, meliputi:

a. Kegairahan atau semangat pemimpin di dalam menghadapi tugas-tugas dan berbagai kondisi atau permasalahan yang dihadapi bawahannya, serta sikap ketelitian dan kepekaan terhadap suasana kerja bawahannya. Terry (2006: 124) menggambarkan ciri mengenai kepemimpinan dari pemimpin yaitu motivasi pribadi, maksudnya pemimpin harus mempunyai keinginan untuk menjadi pemimpin dan dapat memotivasi diri sendiri.

b. Tingkat inisiatif pemimpin untuk mengembangkan cara-cara bekerja lebih efisien dan efektif. Terry, (2006: 124), menggambarkan ciri mengenai kepemimpinan dari pemimpin yaitu memiliki kemampuan teknik, atau kecakapan menganalisis, merencanakan, mengorganisasikan wewenang, mengambil keputusan, dan mampu menyusun konsep.

c. Tingkat pemberian kepercayaan kepada bawahan untuk melaksanakan tugas-tugas yang dianggap penting dan keleluasaan untuk berpendapat dan mengajukan saran-saran kepada pimpinan tentang suatu sekolah. Terry (2006: 124), ciri pemimpin yang energik maksudnya seorang pemimpin mempunyai kekuatan mental dan fisik; stabilitas emosi, tidak boleh mempunyai prasangka jelek terhadap bawahannya, tidak cepat marah, harus mempunyai kepercayaan diri yang cukup besar, dan mempunyai pengetahuan tentang hubungan antar manusia.

\section{Dimensi Kepemimpinan: Perhatian}

Hemphil (1957: 7) dalam The Ohio State Leadership Studies menyarankan bahwa consideration (pertimbangan atau perhatian) adalah aspek penting dari kepemimpinan yang efektif. Penelitian ini menyarankan bahwa pemimpin yang dapat mempertahankan kepercayaan timbal balik, penghargaan, dan kehangatan yang pasti serta pendekatan dengan anggota kelompok akan lebih efektif. Pada saat yang sama, The Office of Strategic Services mengembangkan suatu proses pengukuran yang didasarkan pada penelitian Murray tentang penelitian kemampuan non-kognitif sebaik kemampuan kognitif. Proses ini mengembangkan "assesment center" yang pertama kali dipergunakan dalam sektor privat pada tahun 1956. Banyak dimensi yang diukur dalam assesment center ini dan melibatkan kompetensi-kompetensi sosial dan emosional, seperti sensitifitas, inisiatif, dan keterampilan sosial (Stein: 2002: 32).

Dalam buku Emotional Intelligence, kecerdasan emosional atau emotional intelligence adalah kemampuan mengenali perasaan kita sendiri dan perasaan orang lain, kemampuan memotivasi diri sendiri, dan kemampuan mengelola emosional dengan baik pada diri sendiri dan dalam hubungannya dengan orang lain. Goleman (2015a: 38) adalah salah seorang yang mempopulerkan jenis kecerdasan manusia lainnya yang dianggap sebagai faktor penting yang dapat mempengaruhi terhadap prestasi seseorang.

Dari uraian tersebut, dapat dikatakan bahwa kecerdasan emosional sebagai kemampuan memantau dan mengendalikan perasaan sendiri dan orang lain, serta menggunakan perasaanperasaan itu untuk memandu pikiran dan tindakan. 
Meyer (2004: 58) menyatakan bahwa kecerdasan emosional adalah kemampuan khusus untuk membaca perasaan terdalam mereka yang melakukan kontak, dan menangani relasi secara aktif. Sementara pada saat yang sama dapat memotivasi diri sendiri, dan memenuhi tantangan manajemen relasi. Adapun indikator kecerdasan emosional dalam konteks dimensi perhatian dalam kepemimpinan adalah:

a. Tingkat perhatian pemimpin terhadap hasil kerja dan cara pelaksanaan tugas bawahannya.

Seorang pemimpin dapat memimpin dengan baik, apabila salah satu penekanan fokus kepada anak buah (Ambar: 2008: 65). Anak buah/kolega merupakan pihak yang memiliki hubungan langsung dengan pelaksanaan tugas yang sangat menentukan keberhasilan kepemimpinan seseorang. Apabila bawahan memiliki perilaku dan komitmen tinggi terhadap segala perintah, tugas, tanggung jawab maka akan melancarkan proses kepemimpinan seseorang. Sebaliknya jika bawahan mempunyai perilaku yang tidak sesuai maka akan menghambat kelancaran atau keberhasilan kepemimpinan seseorang.

b. Perhatian pemimpin terhadap nasib bawahannya yaitu berkaitan dengan perhatian pemimpin terhadap hak-hak bawahannya.

Besarnya peranan bawahan dalam kepemimpinan tidak dapat diabaikan. Oleh karena posisinya yang strategis, maka pihak bawahan ini harus diperhatikan oleh pihak pimpinan. Bawahan tidak boleh hanya dipandang sebagai alat untuk mencapai tujuan, sebab bawahan juga mempunyai kebutuhan, kepentingan dan harapan. Menurut Ambar (2008: 59), harapan-harapan tersebut ada empat yaitu need for independence (kebutuhan untuk mandiri), interested in the problem and feel that it's important (ketertarikan dan menganggap penting suatu masalah), understand and identifity with the goal (memahami dan identifikasi tujuan), dan to expect to share in decision making (harapan terlibat dalam pengambilan keputusan).

c. Perhatian pemimpin terhadap kesejahteraan rumah tangga bawahannya dan keakraban hubungan pemimpin dengan bawahannya.

\section{Kepemimpinan Sekolah dengan Kecerdasan Emosional}

Kecerdasan emosional memiliki empat inti kecerdasan, yaitu kesadaran diri, pengelolaan diri, kesadaran sosial, dan pengelolaan relasi. Keempat inti tersebut saling terkait erat dalam suatu relasi yang dinamis. Maksudnya, kesadaran diri akan memungkinkan empati dan pengelolaan diri, dan gabungan kedua hal ini memungkinkan pengelolaan relasi yang efektif (Goleman, 2015b: 34).

Tugas utama pemimpin adalah membangkitkan kegembiraan, optimisme, dan gairah dalam melaksanakan pekerjaan, serta menumbuhkan atmosfer kerjasama dan kepercayaan (Goleman, 2015b: 34). Dengan demikian apabila mampu melakukan hal itu, akan menjadi pemimpin yang baik. Pemimpin yang baik adalah pemimpin yang lebih banyak memiliki sikap perasaan positif terhadap lingkungannya.

Keseimbangan emosional juga merupakan faktor penting dalam usaha kepemimpinan (Gerungan, 1981: 139). Pemimpin yang lebih banyak memiliki sikap perasaan positif terhadap lingkungannya dan memiliki keseimbangan emosional merupakan pemimpin yang demokratis.

Kepala sekolah selaku pemimpin sekolah bukan satu-satunya determinan bagi efektif tidaknya suatu sekolah karena masih banyak faktor lain yang perlu diperhitungkan. Ada guru yang dipandang sebagai faktor kunci yang berhadapan langsung dengan para siswa dan masih ada lagi 
sejumlah masukan instrumental dan masukan lingkungan yang mempengaruhi proses pembelajaran. Namun, kepala sekolah memainkan peran yang sangat menentukan. Studi dengan pendekatan sosiologi tentang efektivitas sekolah menengah menunjukkan bahwa kepemimpinan kepala sekolah memainkan peran yang sangat penting (Depdiknas, 2005: 5).

\section{Karakter Kepemimpinan di SMK Muhammadiyah Suruh}

\section{Dimensi Inisiatif Pemimpin}

Dimensi inisiatif dalam penelitian ini adalah dalam hal kegairahan atau semangat pemimpin dalam menghadapi tugas-tugas dan berbagai kondisi atau permasalahan yang dihadapi bawahannya, serta sikap ketelitian dan kepekaan terhadap suasana kerja bawahannya. Ciri-ciri orang berinisiatif menurut Goleman (2015c) adalah sebagai berikut: (1) siap memanfaatkan peluang, (2) mengejar sasaran lebih daripada yang dipersyaratkan atau diharapkan dari mereka, (3) berani melanggar batas-batas dan aturan-aturan yang tidak prinsipil bila perlu tugas dapat dilaksanakan, (4) mengajak orang lain melakukan sesuatu yang tidak lazim dan bernuansa petualangan.

Kegairahan atau semangat pemimpin di dalam menghadapi tugas-tugas dalam berbagai kondisi bisa dilihat dari hasil wawancara. Dari hasil wawancara (Efendi, 2019) diperoleh data bahwa kepala sekolah memiliki visi pribadi dalam usahanya mengimplementasikan visi dan misi sekolah. Visi pribadi tersebut salah satunya berupa pendirian sebuah lembaga berorientasi keuntungan atau lembaga yang menghasilkan uang yang dimiliki sekolah. Ide yang disampaikan kepala sekolah ini sebenarnya merupakan sesuatu yang tak lazim dalam pengelolaan sekolah. Namun, ketidaklaziman tersebut menjadikan nuansa tantangan dan petualangan yang pada akhirnya ide itu kemudian mampu disosialisasikan sebagai upaya peningkatan mutu pembelajaran yang telah tersusun, disebarluaskan, dikomunikasikan dan dilaksanakan dengan baik, serta didukung oleh komunitas sekolah.

Semangat pemimpin di dalam menghadapi permasalahan yang dihadapi bawahannya bisa dilihat dari pemahaman kepala sekolah tentang kondisi sekolah swasta. Salah satunya adalah fakta bahwa sumber dana utama sekolah swasta adalah iuran orang tua siswa, yang menurut kepala sekolah, warga sekolah tidak hanya dalam kondisi cukup saja melainkan harus dalam kondisi makmur.

Berdasarkan wawancara yang dilakukan peneliti dan kepala sekolah mengenai pembukaan program Teknik Garmen sebagai program keahlian baru, diperoleh kesimpulan bahwa terdapat peluang yang menjanjikan, baik ditinjau dari perspektif sekolah ataupun dari siswa. Dari sudut pandang siswa, lulusan SMK Muhammadiyah Suruh memiliki probabilitas yang tinggi untuk diterima di industri garmen. Lebih dari itu, pihak perusahaan bahkan bersedia memberikan pelatihan selama tiga bulan bagi calon tenaga kerja. Dari sudut pandang sekolah, pemerintah bersedia untuk memberikan bantuan pendanaan re-enginering, yang hanya diberikan kepada sekolah yang mampu memanfaatkan keunggulan lokal, sementara itu, menurut kepala sekolah, industri garmen merupakan keunggulan lokal yang dimiliki Kabupaten Semarang (Efendi, 2019).

\section{Inisiatif Pemimpin untuk Mengembangkan Cara Kerja Efektif dan Efisien}

Suatu organisasi yang cerdas secara emosional bercirikan: 1) membangun sistem yang benar, 2) menciptakan kultur sekolah yang benar, 3) merekrut orang-orang yang tepat, dan 4) mengajukan 
strategi yang tepat. Sebagai sebuah organisasi yang menjadi kebijakan, praktik, dan gaya manajemennya, harus selalu berusaha: 1) membangun aliansi strategis, 2) menyiapkan perubahan secara periodik, 3) memimpin dengan teladan, 4) memberdayakan setiap orang dalam tim, 5) memfokuskan pada kebutuhan dan harapan pelanggan, 6) menyeimbangkan kerja yang cerdas dengan relasi yang cerdas, dan 7) membangun dan mengembangkan "think tank" (wadah pemikir) (Meyer, 2006: 123).

Kepala sekolah dalam usahanya mengembangkan cara-cara bekerja yang lebih efektif dan efisien dengan cara membuat standar mutu manajemen. Standar mutu ini memuat hak dan kewajiban semua warga sekolah, mulai dari kepala sekolah sampai dengan penjaga sekolah. Tak terkecuali kepala sekolah, duduk bersama membuat aturan bersama untuk cita-cita bersama serta dilakukan evaluasi dan perbaikan di setiap semesternya.

Sistem manajemen mutu SMK Muhammadiyah Suruh menempatkan semua warga sekolah sebagai hal yang penting. Prinsip manajemen mutu yang ada yaitu menulis apa yang akan dilakukan dan melakukan apa yang telah ditulis. Sistem manajemen mutu di SMK Muhammadiyah Suruh berupaya mengembangkan dan membina seluruh potensi sekolah dan potensi peserta didik untuk membentuk sumber daya/lulusan yang KAMIL (Kompeten dalam penguasaan ketrampilan teknis, Amanah dalam menjalankan tugas, Mandiri dalam berkreasi dan inovasi, Integritas dalam berperilaku, Luas dalam berwawasan). Dengan pengembangan organisasi menuju kearah yang TEGAR (Terarah dalam membangun mutu organisasi, Edukatif selalu berpijak pada prinsip-prinsip pendidikan, Gerak selalu bergerak untuk perubahan, Akomodatif dapat menerima saran masukan demi perbaikan, Ramah dalam memberikan pelayanan yang bersahabat) (Efendi, 2019).

Dalam supervisi pembelajaran yang dilakukan oleh kepala sekolah, yang sering dilakukan yaitu pemeriksaan administrasi pembelajaran. Hal itu sengaja dilakukan oleh kepala sekolah dengan alasan kerja kepala sekolah berfokus pada persoalan administrasi sekolah lebih mudah dilaksanakan karena lebih objektif. Apalagi peran administrasi pembelajaran sebagai bagian dari administrasi sekolah yang secara praktis menjadi bahan penilaian utama pada saat akreditasi sekolah. Administrasi pembelajaran menjadi fokus pengawasan pada saat melaksanakan tugasnya di samping manajerial sekolah. Dengan melihat keseluruhan administrasi yang menjadi kewajiban guru, maka kepala sekolah telah memperoleh gambaran tentang bagaimana seorang guru bekerja.

Jadwal supervisi pembelajaran sudah direncanakan awal tahun pelajaran. Arahan secara umum program supervisi ada dua, yakni administrasi dan kunjungan kelas untuk proses pembelajarannya. Program pengumpulan administrasi pembelajaran di SMK Muhammadiyah Suruh meliputi perencanaan pembelajaran, komponen pembelajaran, komponen rencana pembelajaran dan kegiatan pembelajaran dalam satu semester.

Pembinaan profesional guru dilakukan secara umum pada saat rapat, dan juga waktu-waktu tertentu yang dikhususkan untuk me-refresh guru dan karyawan, seperti dalam In House Training (IHT). Ada pula kegiatan berupa workshop strategi pembelajaran, penyusunan kurikulum, penyusunan rencana pembelajaran, dan pembagian jam mengajar bagi guru. Pengelolaan waktu dalam melakukan pembinaan ini sengaja dilakukan kepala sekolah, selain untuk efektifitas dan efisiensi waktu, juga untuk menghindari ketidaksukaan guru apabila kekurangan dalam pembelajaran diungkapkan secara terbuka (Efendi, 2019). 


\section{Pemberian Kepercayaan dalam Distribusi Tugas}

Kepala sekolah dalam perannya sebagai pemimpin sekolah mampu menggerakkan orang lain agar secara sadar dan sukarela melaksanakan kewajibannya secara baik sesuai dengan apa yang diharapkan pimpinan dalam mencapai tujuan. Hai ini sesuai dengan pengakuan Wakil Kepala Sekolah Bidang Kurikulum, Bambang Sudiyono (2019), dalam penyusunan sistem pengelolaan sekolah, kepala sekolah, wakil, guru, administrasi sekolah sampai dengan perwakilan siswa duduk bersama saling memberikan pendapat dan masukan dalam posisi setara. Hal ini menjadikan setiap komponen sekolah menjadi penting.

Sistem pengelolaan sekolah di SMK Muhammadiyah Suruh merupakan komitmen bersama, sehingga semua komponen sekolah berhak dan wajib tahu menyangkut tugas, wewenang, kewajiban, dan hak masing-masing. Dengan sistem yang ada, kepala sekolah menciptakan sinergi dalam upaya mencapai sasaran bersama. Orang dengan kecakapan ini bercirikan: a) menjadi teladan dalam kualitas tim seperti respek, kesediaan membantu orang lain dan kooperasi, 2) mendorong setiap anggota tim agar berpartisipasi secara aktif dan penuh antusiasme, 3) membangun identitas tim, semangat kebersamaan dan komitmen (Goleman, 2015c: 350).

Hal ini semakin nampak dalam penyusunan Rencana Strategi (Renstra) yang ada dan direncanakan awal tahun pelajaran untuk jangka waktu lima tahun ke depan, dibuat bersama antara wakil kepala sekolah bidang kurikulum dan pengajaran, wakil kepala sekolah bidang kesiswaan, wakil kepala sekolah bidang sarpras, wakil kepala sekolah bidang hubungan masyarakat, kepala TU, dan ketua program keahlian. Apabila ditinjau dari kegiatan ini, bisa dipersepsikan dalam kepemimpinan, kepala sekolah mengutamakan kepentingan para guru, karena merekalah yang terlibat secara langsung dalam proses pendidikan. Hal ini menghindarkan diri dari sikap dan perbuatan yang bersifat memaksa atau bertindak keras terhadap guru, staf, dan para siswa.

Dalam setiap pembinaan, kepala sekolah selalu mengingatkan dan mengajak semua komponen sekolah untuk berfikir, berinovasi, dan bersinergi dalam menumbuhkembangkan sekolah yang pada gilirannya akan meningkatkan kesejahteraan warga sekolah. Dengan demikian kepala sekolah mampu melakukan perbuatan yang melahirkan kemauan untuk bekerja dengan penuh semangat dan percaya diri terhadap guru. Staf dan para siswa dengan cara meyakinkan dan membujuknya. Penulis melihat kepala sekolah mampu meyakinkan para guru, staf, dan siswa percaya bahwa apa yang dilakukan adalah benar. Kepala sekolah mampu membujuk dan meyakinkan para guru, staf, dan siswa bahwa apa yang dilakukan adalah benar (Sudiyono, 2019).

Pada kesempatan wawancara yang lain, berkaitan dengan mengimplementasikan program kerja dan mewujudkan Renstra yang ada, kepala sekolah berusaha untuk selalu menyosialisasikan terlebih dahulu, namun pada saat-saat tertentu terpaksa kepala sekolah mengambil langkah terlebih dahulu baru menyosialisasikan atau memberikan penjelasan. Namun semua langkah yang dilakukan tetap dalam bingkai untuk mengembangkan sekolah. Langkah yang cepat, kalau harus disosialisasikan terlebih dahulu membutuhkan waktu lama karena heterogennya komponen sekolah selain karena banyaknya kompetitor. Langkah yang dilakukan kepala sekolah, terkadang membuat beberapa guru bingung atau tidak paham. Pada awalnya beberapa guru nggrundhel (mengeluh) dan kecewa merasa tidak diuwongke (tidak diberi peran). Namun setelah itu, langkah kepala sekolah tersebut membuat beberapa guru lebih percaya diri dan sejahtera (Sudiyono, 2019). 
Berdasarkan pengamatan yang dilakukan oleh penulis, kepala sekolah berusaha untuk selalu menghargai dan mempercayai rekan sejawat. Namun, pada saat-saat tertentu ternyata tidak bisa dilaksanakan dengan maksimal, bukan karena tidak menghargai rekan sejawat melainkan karena harus berlomba dengan sekolah lain. Dengan demikian, diharapkan pengertian dari para bawahan dan rekan sejawat.

\section{Perhatian Pemimpin terhadap Hasil Kerja dan Cara Pelaksanaan Tugas Bawahan}

Perhatian yang dimaksudkan adalah empati yang dilakukan kepala sekolah SMK Muhammadiyah Suruh. Empati dilandasi oleh kesadaran posisional, di mana kepala sekolah membayangkan dirinya berada pada posisi yang dipimpin (Efendi, 2019). Hal ini nampak pada data dokumen yang ada, dari hasil wawancara dan observasi terhadap setiap kegiatan sekolah, baik itu ulangan semester, ujian penerimaan siswa baru, dan lainnya pasti dibentuk panitia pelaksana. Panitia pelaksana wajib membuat proposal yang sekurangnya berisi susunan panitia, program kegiatan, jadwal pelaksanaan, dan pendanaannya. Yang dimaksudkan pendanaan adalah biaya pelaksanaan kegiatan hingga honor kepanitiaan, yang dianggap final apabila semua anggota panitia pelaksana telah membubuhkan tanda tangan sebagai tanda persetujuan. Perilaku ini sengaja dilakukan sebagai pengalaman pribadi ketika menjadi bawahan merasa diremehkan. Untuk itu kepala sekolah berusaha untuk tidak membuat sakit hati bawahannya dengan memberikan kepercayaan penuh termasuk pada nominal honor. Langkah seperti ini dianggap oleh kepala sekolah sebagai upaya manajemen anak buah.

Apa yang dilakukan kepala sekolah tersebut ternyata sesuai dengan perusahaan dengan kecerdasan emosional. Perusahaan dengan kecerdasan emosional bercirikan beban kerja yang sesuai, otonomi bawahan, imbalan yang memadai, sambung rasa, perlakuan adil, dan tidak ada konflik nilai (Goleman, 2015c: 468-470).

Semua kegiatan yang telah terprogram tersebut selalu dipantau oleh kepala sekolah. Menurut kepala sekolah, maju atau tidaknya SMK Muhammadiyah Suruh adalah kerja bersama, sehingga sebagai sebuah sistem, peran sekecil apapun perlu dihargai. Kepala sekolah sebagai pemimpin menghormati sistem dan menempatkan dirinya sejajar dengan bawahannya. Jabatan kepala sekolah itu sementara, atau ada masa waktunya, sehingga untuk menjaga keajegan (kontinuitas) sistem, perlu saling menularkan atau saling belajar.

Kepala sekolah (Efendi, 2019) menyadari bahwa maju mundurnya sekolah merupakan hasil kerja bersama, bukan individu. Sebagai sebuah kerja sama maka dapat dikatakan menjadi sebuah sistem yang kait-mengkait, maka semua memiliki peran yang sama pentingnya. Tidak ada yang paling penting, sekecil apapun peran itu perlu dihargai.

Kepala sekolah SMK Muhammadiyah Suruh memiliki sebutan yang unik untuk menyebut para pengajar di sekolah ini, sebagai bentuk perhatian dari pemimpin kepada bawahannya. Sebutan ini bisa dimaknai sebagai sebutan yang egaliter, karena menggunakan istilah "teman-teman". Pada awalnya istilah ini dianggap oleh guru sebagai sebuah kelalaian, namun seiring dengan seringnya guru menemani kepala sekolah, dan berkali-kali disebut "teman-teman" oleh kepala sekolah untuk menunjuk para guru, maka akhirnya berubah menjadi kebiasaan dan dimaknai secara positif. Bahkan, pada saat-saat tertentu, menjadikan para pengajar merasa tersanjung. Dengan demikian kepala sekolah sudah memiliki adaptabilitas yaitu keluwesan dalam menanggapi perubahan dan 
tantangan. Adaptabilitas dari kepala sekolah SMK Muhammadiyah Suruh yang ditemukan dalam penelitian merupakan wujud dari sikap asertif.

Sikap asertif menurut Stein (2002: 89-90) adalah kemampuan untuk berkomunikasi dengan jelas, spesifik dan tidak multi tafsir, sambil sekaligus tetap peka terhadap kebutuhan orang lain dan reaksi mereka dalam peristiwa tertentu. Pengungkapan sikap asertif kepala sekolah ditunjukkan dengan memiliki kesadaran diri yang memadai sehingga bisa mengenali perasaan sendiri sebelum mengungkapkannya. Selain itu kepala sekolah juga mampu mempertahankan hak-hak pribadi, alasan pribadi dan nilai-nilai yang sangat diyakini kebenarannya. Perhatian pemimpin terhadap nasib bawahannya yaitu berkaitan dengan perhatian pemimpin terhadap hak-hak bawahannya.

Ada enam faktor utama penyebab turunnya moral dan motivasi karyawan di perusahaan, yaitu: beban kerja yang berlebihan, kurangnya otonomi, imbalan yang tidak memadai, hilangnya sambung rasa, perlakuan tidak adil, dan konflik nilai. Imbalan yang tidak memadai yang dimaksud adalah berupa upah yang terlalu kecil untuk pekerjaan yang lebih banyak. Selain itu imbalan yang menyangkut emosi, beban kerja berlebihan ditambah terbatasnya wewenang serta tidak terjaminnya kelangsungan pekerjaan berakibat hilangnya kenikmatan bekerja yang seharusnya ada dalam pekerjaan (Goleman, 2015c: 469).

Menurut hasil wawancara dengan bendahara sekolah (Maskuroh, 2019), dalam penyusunan RAPBS (Rencana Anggaran Pemasukan dan Belanja Sekolah), yang berkaitan dengan pengeluran rutin atau honor untuk guru dan karyawan terlebih dahulu diselesaikan, baru kegiatan lainnya. Kegiatan-kegiatan lainnya sudah disusun oleh pejabat yang berwenang antara lain ketua program keahlian, kesiswaan dan lain-lain. Dalam pelaksanaan anggaran, biasanya oleh kepala sekolah ada beberapa anggaran yang ditahan atau tidak dicairkan terlebih dahulu. Hal ini biasanya berdasarkan masukan dan informasi dari bendahara sekolah.

Kepala tata usaha (KTU), para wakil kepala sekolah dan ketua program keahlian diberikan haknya untuk menyusun program kerja sekolah selama satu tahun beserta penganggarannya. Dengan demikian semua komponen sekolah tahu persis akan keuangan sekolah. Dalam pembahasan RAPBS bersama Yayasan Muhammadiyah Suruh dan disahkan oleh Majelis Pendidikan Dasar dan Menengah Pimpinan Cabang Muhammadiyah Suruh. Perhatian pemimpin tehadap nasib bawahannya yaitu berkaitan dengan perhatian pemimpin terhadap hak-hak bawahannya berupa pemberian gaji sesuai UMR (upah minimum regional) Kabupaten Semarang bagi pegawai tetap yayasan, honor kelebihan mengajar, uang transport harian, wisata keluarga, tunjangan kesehatan, dan tunjangan jabatan. Termasuk memperhatikan semua guru untuk mendapatkan tunjangan sertifikasi guru (Maskuroh, 2019).

\section{Keakraban Hubungan dan Perhatian Pemimpin terhadap Kesejahteraan Bawahan}

Perhatian kepala sekolah terhadap kesejahteraan bawahannya dilakukan dengan cara selalu njagani (menyiapkan) pembayaran untuk 1 tahun ke depan. Hal ini sengaja dilakukan untuk memberikan kepercayaan kepada organisasi sekolah bahwa kepala sekolah dan yayasan bertanggung jawab terhadap nasib para pemangku sekolah, sehingga rasa bahagia dari para guru dan karyawan bisa memotivasi mereka untuk bekerja dengan maksimal (Nurochim \& Ngaisah, 2020).

Keakraban hubungan didasari empati yang dimulai dari dalam hati. Kemampuan mengindera perasaan seseorang sebelum yang bersangkutan mengatakannya merupakan intisari empati 
(Goleman, 2015c: 214). Orang jarang mengungkapkan perasaan mereka lewat kata-kata; sebaliknya mereka memberitahu lewat nada suara, ekspresi wajah, atau cara-cara non-verbal lainnya.

Kepala sekolah menyadari posisi sebagai pemimpin berkewajiban selalu berpikir, berusaha dan bertindak untuk kepentingan sekolah dan komponen sekolah. Melalui kesadaran ini maka kepala sekolah telah mengungkapkan empati dan dengan empati yang ditampilkan oleh kepala sekolah menjadikan rekan sejawat merasa dirinya dimengerti. Langkah ini ternyata bisa meredakan ketegangan yang terjadi antara guru dan kepala sekolah. Terbukti dengan banyak guru yang berkomentar posistif terhadap kepemimpinan kepala sekolah, dibandingkan komentar yang negatif (Maskuroh, 2019).

Dari semua analisis tersebut di atas, menunjukkan bahwa kepemimpinan sekolah di SMK Muhammadiyah Suruh Kabupaten Semarang dalam bekerja telah melibatkan emosi secara cerdas, baik dalam hal kemampuan kesadaran diri, kemampuan pengelolaan diri, maupun kemampuan pengelolaan kesadaran sosial. Dalam kemampuan kesadaran diri, kepala sekolah mampu bicara terbuka tentang emosinya atau dengan keyakinan tentang visi dalam mengelola sekolah serta dengan percaya diri menerima kritik dan umpan balik yang membangun; kemampuan dalam pengelolaan diri terwujud bahwa kepala sekolah mampu mengendalikan diri, transparan, dan menyesuaikan diri; kemudian kemampuan dalam kesadaran sosial nampak dengan adanya relasirelasi yang penting bagi sekolah serta mampu bekerja secara tim dan berkolaborasi.

\section{Kesimpulan}

Sesuai dengan tujuan penelitian untuk mendeskripsikan karakteristik kepemimpinan sekolah dalam perspektif kecerdasan emosional di SMK Muhammadiyah Suruh, maka temuan hasil penelitian dapat disimpulkan bahwa kepala sekolah memiliki semangat dalam menghadapi tugastugas dan berbagai kondisi atau permasalahan yang dihadapi bawahannya, serta sikap ketelitian dan kepekaan terhadap suasana kerja bawahannya selalu dikoordinasikan dengan pejabat sekolah dan Yayasan untuk lebih maju dan berkembang. Selain itu, adanya inisiatif pemimpin untuk mengembangkan cara-cara bekerja yang lebih efektif dan efisien lebih difokuskan dalam pembenahan administrasi sekolah.

Karakter lain yang ditunjukkan oleh kepala sekolah adalah pemberian kepercayaan kepada bawahan untuk melaksanakan tugas-tugas yang dianggap penting, keleluasaan untuk berpendapat dan mengajukan saran-saran kepada pimpinan tentang ide pengembangan sekolah, serta lebih banyak mendengarkan guru dengan berdiskusi atau memberikan alternatif-alternatif pemecahan ketimbang mendominasi pembicaraan. Hal ini diwujudkan dengan tingkat perhatian terhadap hasil kerja dan cara pelaksanaan tugas bawahannya yang sudah baik, terbukti dengan berbagai prestasi yang telah dicapai baik oleh guru maupun siswa, mulai dari tingkat kabupaten hingga tingkat nasional.

Perhatian pemimpin terhadap nasib bawahannya yaitu berkaitan dengan perhatian pemimpin terhadap hak-hak bawahannya juga sudah baik, terbukti dalam pemberian gaji sesuai UMR (upah minimum regional) Kabupaten Semarang bagi pegawai tetap yayasan, honor kelebihan mengajar, uang transport harian, wisata keluarga, tunjangan kesehatan dan tunjangan jabatan. Selain peningkatan penghasilan, perhatian pemimpin juga dilakukan dalam hal peningkatan keterampilan dan pengetahuan guru, berupa pengiriman guru dan karyawan untuk mengikuti workshop dan 
berbagai kegiatan lainnya. Hal ini dimaksudkan untuk meningkatkan pelayanan sekolah yang prima serta meningkatkan mutu dan keterampilan peserta didik, sehingga meningkatkan juga kepercayaan masyarakat yang terwujud dalam makin banyaknya jumlah peserta didik yang berminat masuk di SMK Muhammadiyah Suruh.

\section{Daftar Pustaka}

Ambar, T. (2008). Kepemimpinan Profesional. Yogyakarta: Gava Media.

Baisa, H. (2005). Kepemimpinan dan Etos Kerja, Jurnal Khasanah, Vol 1.

Darwin, D. (2014). GELAR PROFESIONAL CALON KEPALA SEKOLAH (SUATU PEMIKIRAN). Jurnal Pendidikan dan Kepengawasan, 2(2). 79-95. https://jurnal.unimed.ac.id/2012/index.php/jpdk/article/view/7962.

Depdiknas. (2006). Standar Kompetensi Kepala Sekolah TK, SD, SMP, SMA, SMK, dan SLB. BP. Jakarta: Cipta.

Fauziyati, W. (2019). Strategi Kepala Sekolah untuk Meningkatkan Partisipasi Masyarakat dalam Pendidikan menuju Generasi Maju Indonesia. QALAMUNA: Jurnal Pendidikan, Sosial, Dan Agama, 10(01). https://doi.org/10.5281/zenodo.3559248.

Gerungan. (1981). Psikologi Sosial. Jakarta- Bandung: PT Eresco.

Goleman, D. (2015a). Emotional Intelligence. Jakarta: Gramedia Pustaka Utama.

Goleman, D. (2015b). Kepemimpinan Berdasarkan Kecerdasan Emosional. Jakarta: Gramedia Pustaka Utama.

Golemen, D. (2015c). Kecerdasan Emosi untuk Mencapai Puncak Prestasi. Jakarta: Gramedia Pustaka Utama.

Meyer, H. (2007). Manajemen dengan Kecerdasan Emosional. Bandung: Nuansa.

Nawawi, H., \& Martini. (2006). Kepemimpinan yang Efektif. Yogyakarta: Gadjah Mada University Press.

Nurochim, N., \& Ngaisah, S. (2020). Pendampingan dalam Memahami Indeks Kebahagiaan Guru di Madrasah Aliyah Negeri (MAN) di Tangerang Selatan. QALAMUNA: Jurnal Pendidikan, Sosial, Dan Agama, 12(1), 1-14. https://doi.org/10.37680/qalamuna.v12i01.213.

Poniman, P., Sumadi, S., \& Hariri, H. (2017). PENGARUH KEPEMIMPINAN KEPALA SEKOLAH, KECERDASAN EMOSIONAL KECERDAAN SPIRITUAL GURU TERHADAP PROFESIONALISME GURU. JURNAL MANAJEMEN MUTU PENDIDIKAN, $5(1)$.

Stein, S. (2002). Ledakan EQ: 15 Prinsip Dasar Kecerdasan Emosional Meraih Sukses. Bandung: Kaifa.

Terry, G. (2006). Prinsip- Prinsip Manajemen. Jakarta: Bumi Aksara.

Wahjosumidjo. (2001). Kepemimpinan Kepala Sekolah. Jakarta: Rajagrafindo Persada.

Wahyuni, E. (2019). HUBUNGAN ANTARA KEPEMIMPINAN TRANSFOMASIONAL KEPALA SEKOLAH DAN KECERDASAN EMOSIONAL DENGAN KEPUASAN KERJA GURU. Tawazun: Jurnal Pendidikan Islam, 11(2), 211. https://doi.org/10.32832/tawazun.v11i2.1530. 
Yusuf, Z., \& Mardiana, D. (2020). Manajemen Berbasis Sekolah sebagai Landasan Kepala Sekolah dalam Peningkatan Mutu Pendidikan Agama Islam. QALAMUNA: Jurnal Pendidikan, Sosial, Dan Agama, 12(1), 71-78. https://doi.org/10.37680/qalamuna.v12i01.152.

\section{Wawancara:}

Efendi, H. (2019). Wawancara Haryu Efendi (Kepala Sekolah).

Maskuroh, L. (2019). Wawancara Lilik Maskuroh (Bendahara Sekolah).

Sudiyono, B. (2019). Wawancara Bambang Sudiyono (Wakil Kepala Sekolah Bidang Kurikulum).

Seluruh wawancara dilaksanakan pada tanggal 13 dan 15 Juli 2019, bertempat di SMK Muhammadiyah Suruh, Semarang. 